\title{
Seismicity Study of Botswana from 1966 to 2012
}

\author{
Bokani Nthaba $^{1 *}$, Rapelang E. Simon ${ }^{2}$, Ghebrebrhan M. Ogubazghi ${ }^{3}$ \\ ${ }^{1}$ Botswana International University of Science and Technology (BIUST), Palapye, Botswana \\ ${ }^{2}$ Physics Department, University of Botswana, Gaborone, Botswana \\ ${ }^{3}$ Department of Earth Sciences, Eritrea Institute of Technology, Asmara, Eritrea \\ Email: *nthaba.bokani@studentmail.biust.ac.bw
}

How to cite this paper: Nthaba, B., Simon, R.E. and Ogubazghi, G.M. (2018) Seismicity Study of Botswana from 1966 to 2012. International Journal of Geosciences, 9, 707-718.

https://doi.org/10.4236/ijg.2018.912043

Received: November 19, 2018

Accepted: December 26, 2018

Published: December 29, 2018

Copyright (๑) 2018 by authors and Scientific Research Publishing Inc. This work is licensed under the Creative Commons Attribution International License (CC BY 4.0).

http://creativecommons.org/licenses/by/4.0/

(c) (i) Open Access

\begin{abstract}
The history of Botswana's major seismic events has been initiated by two earthquakes that occurred on the $11^{\text {th }}$ of September and $11^{\text {th }}$ of October 1952 with ML Richter magnitudes of 6.1 and 6.7, respectively, in the Okavango Delta Region (ODR). Not much is known and well documented about the seismicity of a larger coverage of Botswana primarily because over the years, local seismic stations were biased to the north-western part of Botswana, to monitor the more seismogenic ODR. The objective of this study is to use data from the International Seismological Centre (ISC) bulletin for the period 1966-2012 to estimate the relative size distribution of seismic events ( $b$-value), the rate of seismic activity (a-value), and associated stress condition prevailing in Botswana to assist in the quest of hazard mitigation. This study shows that micro-seismic activities of magnitude ranging from 1.3 to 5.7 are distributed not only on the northern part of Botswana, but also in other parts of the country such as the Southern (including Kweneng East and West), Central and Eastern Botswana. Based on 327 events extracted from data compiled by the ISC, the frequency-magnitude distribution (FMD) of earthquakes in Botswana from 1966 to 2012 was estimated with $b$-value and $a$-value for the entire catalogue found to be 1.2 and 6.3 , respectively, implying a region of low stress dominated by small to moderate events. The minimum completeness magnitude $\left(M_{C}\right)$, a value that indicates the lowest magnitude above which all seismic events are reliably recorded was found to be 3.8. From this analysis, annual probabilities of occurrence for $M 4$ and $M 5$ events were found to be $67.2 \%$ and $4.3 \%$, respectively, while $M 6$ or larger event has an annual probability of $0.3 \%$.
\end{abstract}

\section{Keywords}

$b$-Value, Catalogue, Completeness Magnitude, Okavango Delta Region, 


\section{Introduction}

Botswana is situated centrally on the Precambrian shield of Southern Africa, on a fault line [1], and hosts the world's largest inland delta-the famous Okavango Delta Region (ODR) in the northwest. There has been earthquake swarms in the ODR between 1951 and 1953 [2] [3]. This aroused the interest of researchers and motivated the government to initiate a process of establishing seismological monitoring facilities. In response, the Botswana Geological Survey and the University of Botswana established a network consisting of 9 seismological stations, located in and around the ODR, at the beginning of the current century [4]. The stations were deployed primarily to monitor earthquake events associated with the delta, with its high seismicity attributed to a south-western extension of the East African Rift system [5]. However, as has been made evident recently, seismicity is not limited to the ODR, and small to moderate earthquakes in other regions of the country which have been occurring. These include western part of the Zimbabwe Craton in the east, and northern part of the Kaapvaal Craton in the south.

The objectives of this study is to use data from the International Seismological Centre (ISC) bulletin starting with the year of Botswana's independence, 1966 through to 2012, to determine the magnitude of completeness $\left(M_{C}\right)$, and to estimate the b-value and associated stress condition prevailing in Botswana. The paper is organized in the following manner. We start with a summary of the geology of Botswana; which is followed by a brief description of the methodology used. The $b$-value and the associated stress conditions are then presented; and finally the discussion and the conclusions are given.

\section{Geological Setting}

Rocks of different lithology, age and geological history are exposed in most parts of eastern Botswana. To the north-western Botswana, where the famous Okavango Delta Region is situated, these rocks are buried below the Kalahari sands of Tertiary and Quaternary age [1]. The key to the solid geology of the ODR lies in the surface outcrops in areas surrounding the swamps and in the available bore-holes which have penetrated the sub-Kalahari basement [3]. The oldest rocks in the region are granitoid gneisses of the Archaean Basement Complex. [6] also described ten north-easterly trending rift faults associated with the Okavango Rift Zone, including the Thamalakane, Kunyere, Linyanti, Chobe, Nare, Phuti, Lecha, Tsau, Gumare and Mababe and the east-south easterly trending Sekaka Shear Zone (Figure 1). These faults are, though not verified, the southernmost extensions of the same system of parallel fault lines that are pulling away from each other and have formed East Africa's Great Rift Valley [7]. 


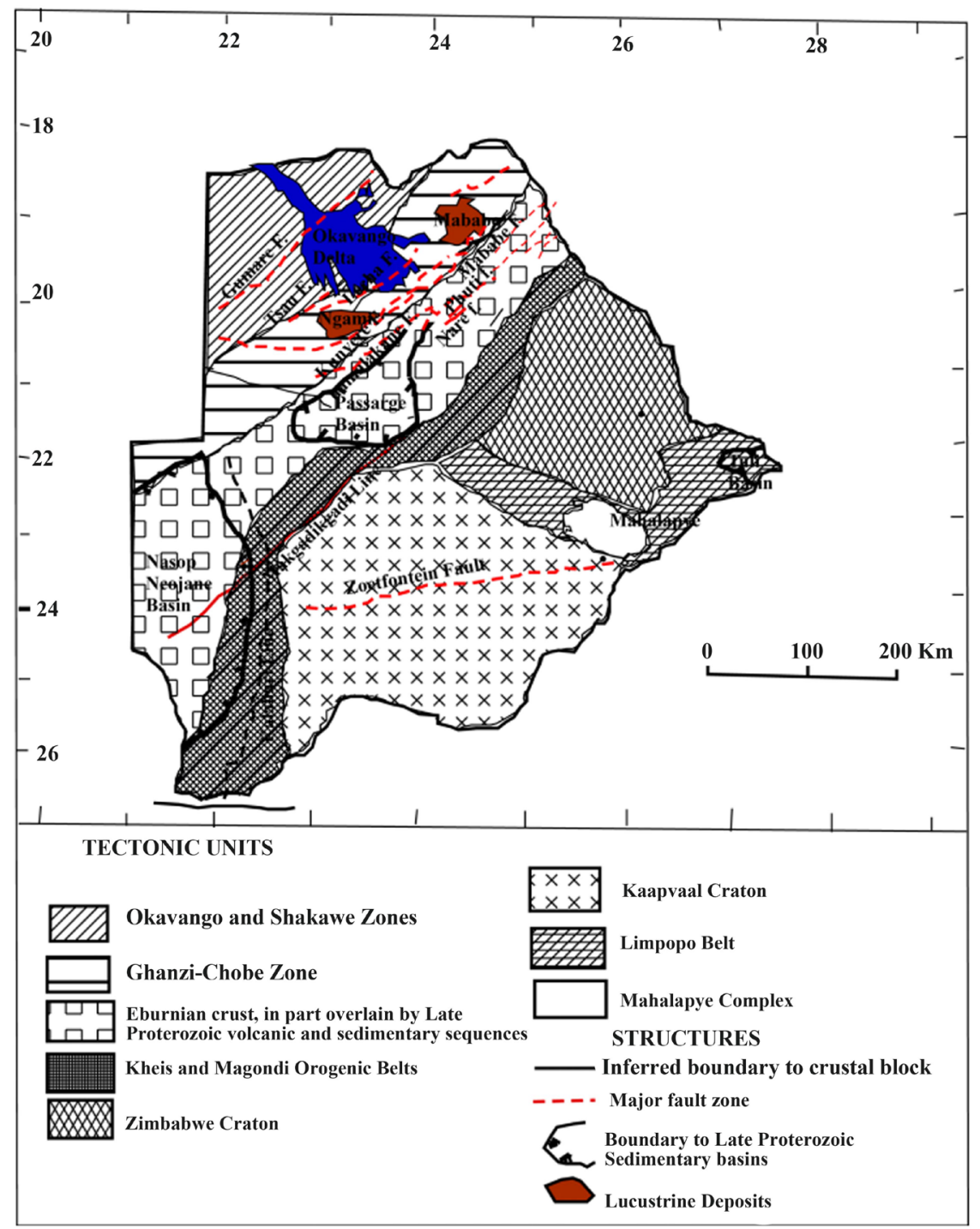

Figure 1. The major structural features and tectonic units in Botswana (Modified from [8] [10]).

A large area of southern Botswana is underlain by the Kaapvaal Craton [8]. The Kaapval craton is limited to the north by the Limpopo Mobile Belt [1], which was formed by a series of tectonic, magmatic and metamorphic events. The western craton margin coincides with the linear, northerly trending geophysical discontinuity known as the Kalahari Line [8]. Early Proterozoic sedimentary rocks that were strongly folded at about $1800 \mathrm{Ma}$ during the Kheis orogeny lie adjacent to at least part of the Kalahari Line. In the eastern boundary, the Kaapvaal Craton is approximately located within a $90 \mathrm{~km}$ wide belt of ground underlain by the Waterberg Group and the Karoo Supergroup sedimentary rocks [8]. The series of events that formed the Limpopo Mobile Belt were followed in early Proterozoic time by the subsidence of the Kaapvaal Craton and the formation of a sedimentary basin in which the Transvaal Supergroup was deposited [1]. A complex assemblage of mylonitic gneiss and syntectonic pink 
granites has been described in the east-northeast trending Palala Shear, which has been reactivated to form sub-parallel post-Karoo faults such as the Melinda Fault [8] [9], and extends into Botswana as the Zoetfontein Fault. The Makgadikgadi Line coincides with a northeast-southwest axis of enhanced seismicity which separates large domains with strongly contrasting gravity and aeromagnetic signatures, also interpreted as a tectonic front [2]. The occurrence of a diamondiferous kimberlite at Gope demonstrates the presence of thick Archaean crust underlying that area, and suggests that this is cratonic in nature [8].

The Zimbabwe Craton within Botswana occupies an area of about $60,000 \mathrm{~km}^{2}$ [8], of which the western half is mantled by Phanerozoic deposits. The craton margins are major tectonic discontinuities. In the south, the Zimbabwe Craton adjoins the Archaean intercratonic terranes of the Limpopo Mobile Belt. In the west, it terminates within the southwesterly extension of the Early Proterozoic Magondi Orogenic Belt [8]. The gneiss and granitoid units constitute about 75\% by area of the Zimbabwe Craton. Rock masses in the Zimbabwe Craton are structurally complex. Most lithologies have been affected by diverse processes of shear deformation, partial melting and magmatic injection [8].

\section{Methodology}

To start the analysis, an earthquake catalogue based on data compiled by the ISC [11] from the year 1966 to 2012, was prepared. An earthquake catalogue contains the location and magnitudes of recorded earthquakes, and can be used to assess rates and locations of future earthquakes [12]. The data covers a period of 46-years from $1^{\text {st }}$ January1966 to $31^{\text {st }}$ December 2012 and a total of 327 events. The first seismic event identified was on February 1966. In order to investigate the variation of seismicity in Botswana a frequency-magnitude distribution plot was established, in which six events with missing magnitudes were not included. Earthquake frequency-magnitude relation helps to understand seismic activity in an area [12]. Parameters of earthquakes that were of interest in this work and extracted from the ISC Bulletins were: year, date, time, latitude, longitude and magnitude (Table 1). From the four possible methods for interactively defining a search region of seismic events within the ISC Bulletin, a rectangular region of known coordinates was used to search for events hypocentres from the years 1966 to 2012.

An online mapping tool known as @ batchgeo [13] was used to produce maps showing the magnitude distribution (Figure 2) and the temporal distribution (Figure 3) of events within the borders of Botswana from the ISC bulletin for the above mentioned period.

\subsection{Frequency Magnitude Distribution (FMD)}

The magnitude distribution of earthquakes has been found to show a power law behaviour when plotted on a logarithmic plot and the distribution is linear [14]. This was first recognized in Japan [15], and later [16] in California, introduced the magnitude-frequency relation of earthquakes (Equation (1)): 
Table 1. Data search summary [11].

\begin{tabular}{ll}
\hline Database & ISC Bulletin \\
\hline Latitude range & $-28^{\circ}$ to $-16^{\circ}$ \\
Longitude range & $19^{\circ}$ to $30^{\circ}$ \\
Start date & $1966 / 01 / 01 \quad 00: 00: 00$ \\
End date & $2012 / 12 / 31 \quad 00: 00: 00$ \\
Search shape & Rectangular region \\
\hline
\end{tabular}

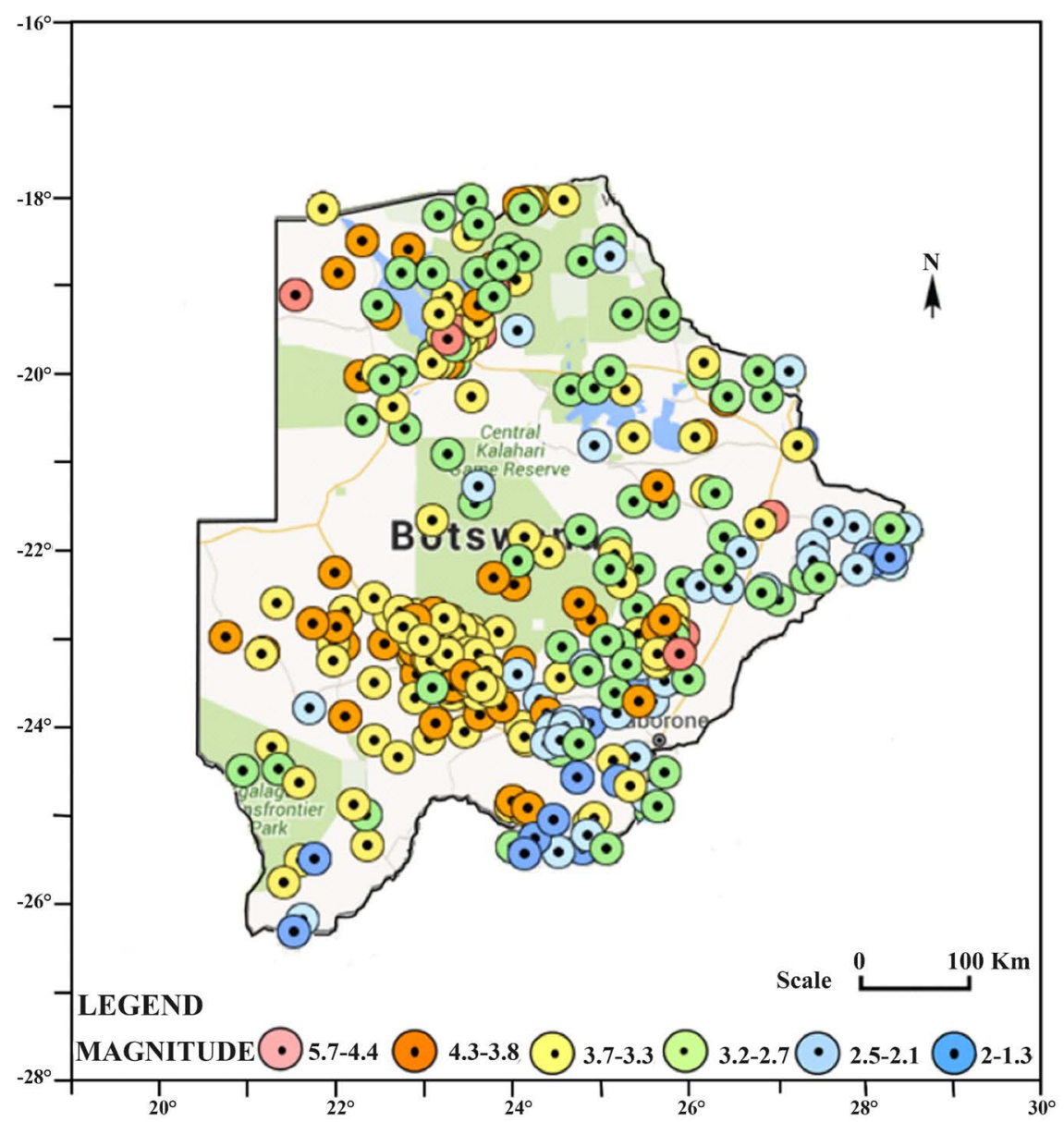

Figure 2. Map showing magnitude distribution of seismic events in Botswana for the period 1966-2012.

$$
\log _{10} N=a-b M,
$$

which provides a good fit to the magnitude distribution (Figure 4), where $N$ represents the cumulative number of earthquakes above a certain magnitude, $M$; a is the parameter obtained from the intercept of the graph of Log $N$ against Magnitude, and defines the rate of earthquakes (seismic activity); $b$ ( $b$-value) is a parameter that defines the slope of the distribution and describes the relative size distribution of earthquakes [17] [18]. This relation depends on the locally determined magnitude of completeness $\left(M_{C}=3.8\right)$, for which all earthquakes 


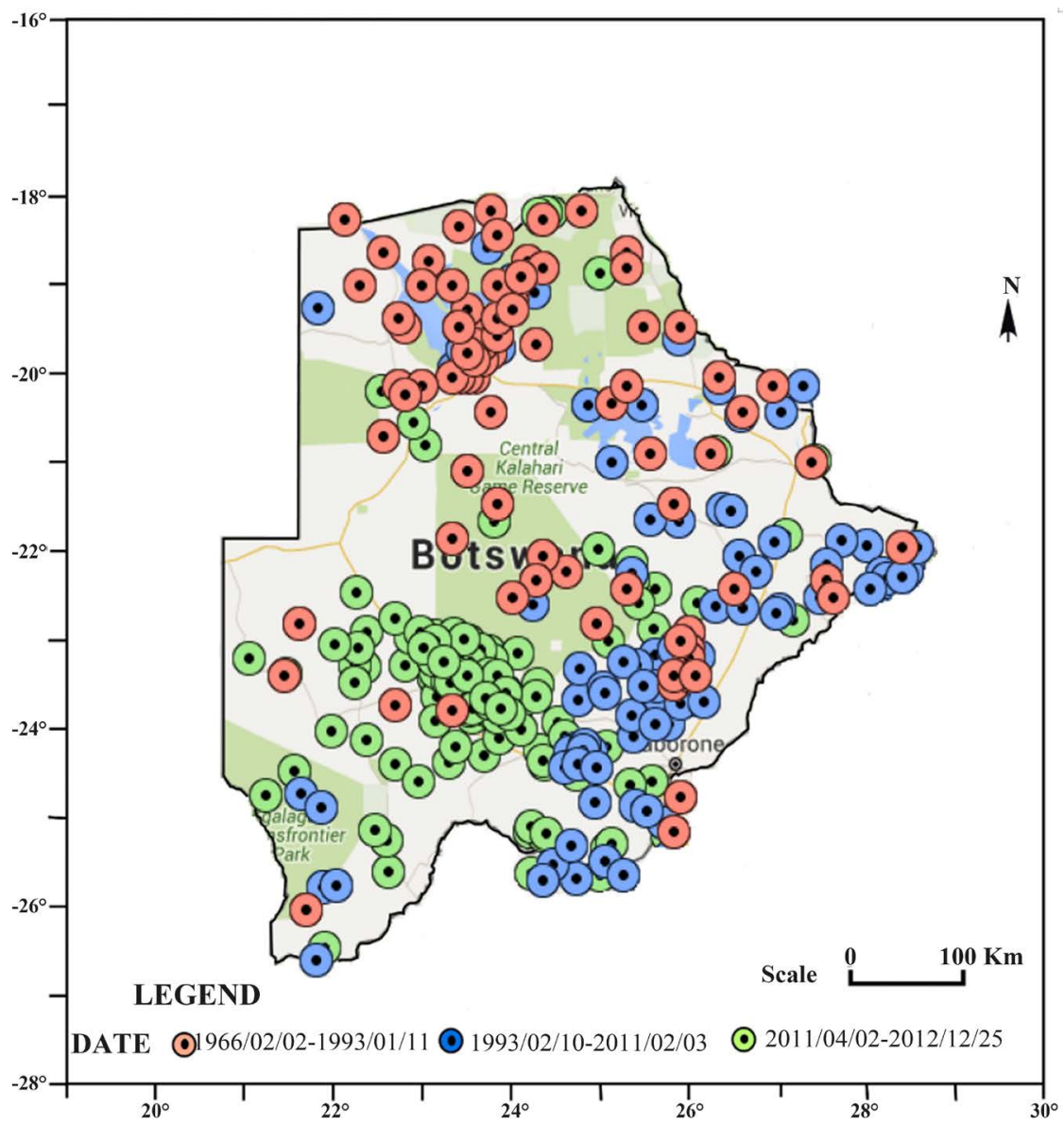

Figure 3. Map showing temporal distribution of seismic events in Botswana for the period 1966-2012.

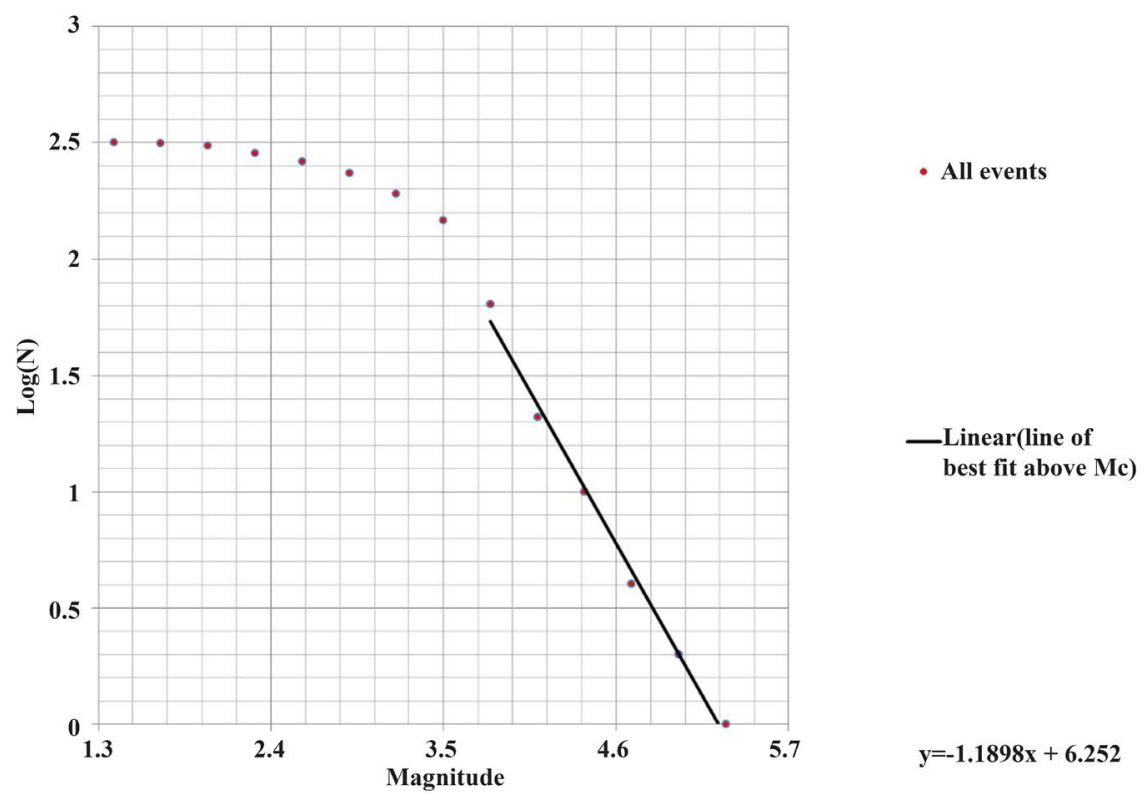

Figure 4. Gutenberg-Richter relation for Botswana events located by ISC for the period 1966 to 2012 . The magnitude is $m_{b}$ determined by ISC and the least squares line showing completeness magnitude. 
above that level are considered to be completely represented in the catalogue (Figure 5). Therefore, a more accurate $M_{C}$ increases the likelihood of determining the actual $b$-value of the distribution, which is an important factor in seismic risk analysis, prediction, and hazard, and its correct computation represents an important challenge as it provides vital information as per seismology of an area [18]. Large value for $b(>1)$ indicates predominantly small earthquakes and indicates an area of low stress, while small $b$-value $(<1)$ implies a relatively larger proportion of large earthquakes and is an indication of highly stressed area [12], [19].

The frequency-magnitude distribution can be used to make a probabilistic hazard forecast [20], by rewriting the Gutenberg-Richter law in terms of probability of a target magnitude $\mathrm{M}_{\mathrm{t}}$ or larger event (Equation (2)):

$$
P\left(M>M_{t}\right)=10^{(a-b M)} / \mathrm{d} T
$$

where $\mathrm{d} T$ is the observation period $(1966-2012=46$ years). Using $a=6.3$ and $b$ $=1.2$ (Figure 4), we find that $M 4$ and $M 5$ events have annual probabilities of about $67.2 \%$ and (4.3\%), respectively, while M6 or larger event has an annual probability of $0.3 \%$.

\subsection{Time Distribution of Seismic Events}

Earthquakes do occur randomly in time [20]. This is the assumption that is commonly made when computing hazard. Changes in the rate can be related to artificially introduced shifts in the magnitude determination [21]. These changes are common in seismicity catalogues and they often remain undetected and can cause a significant change in the rate of earthquakes. Figure 6 shows the time distribution of seismic activity from the years 1966 to 2012 .

\section{Discussions}

Over the years the distribution of seismic stations in Botswana was biased towards Ngamiland and Chobe Districts as a result of deployment approach that targeted the more seismogenic ODR at the time, due to limited resources. Figure 2 shows that most of the events that occurred around the ODR were of moderate

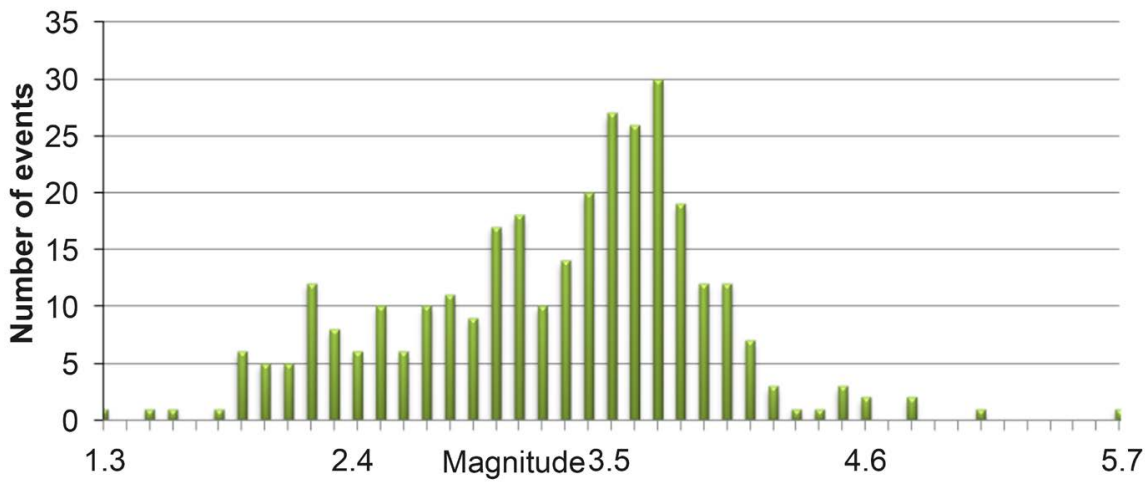

Figure 5. The magnitude bar graph of earthquakes that occurred in Botswana for the period 1966 to 2012 . 


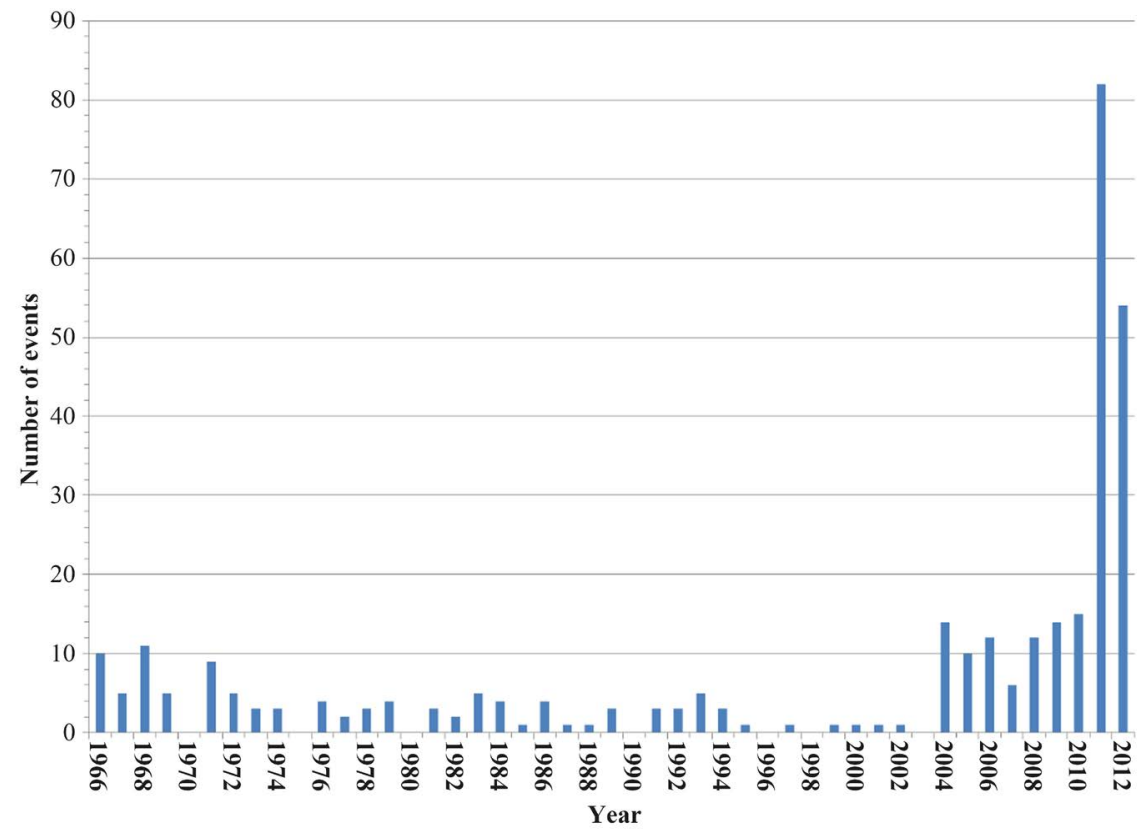

Figure 6. The annual number of earthquakes that occurred in Botswana for the period 1966 to 2012.

magnitudes ranging from 2.7 to 5.7, with those below 2.7 appearing to be minimal and only restricted to the south-eastern Botswana. The temporal seismicity distribution map (Figure 3) indicates that during the period 1966 to 1983 the main area of seismicity was indeed the ODR. Within the delta, seismic activity was highest along the south-eastern edge, where it seems to be associated with the NE-SW striking faults: The Tsau, Lecha, Kunyere, Mababe and the Thamalakane Faults. Seismicity is very low in the central part of the delta and just a few events on the upper side, along the NE-SW striking Gumare Fault. The rate of seismicity recorded between these faults may be associated with both the large volume of water contained in these faults and the continued inflow of large amount of water into the delta.

There was also considerable activity in the region of Mababe Depression between the same period of 1966-1983, with minimal activity in the same region between 2008 and 2011, and lesser activity at the SW end of the delta, around Lake Ngami. The results of this study for this period of 1966-1983 are in agreement with the findings of the study conducted by the Lamont-Doherty Geological Observatory of Columbia University, USA, in association with the Department of Geological Survey, Botswana in 1974 [22] and also in [23], in which the mean place of seismic events distribution was found to be between the Kunyere and the Thamalakane faults.

The role of water and sediment load on seismicity in faulted zones has been discussed by previous researchers, e.g., the geophysical studies of the San Andreas Fault (SAF) by [24] [25] [26] [27]. From the results of their studies, they suggested that seismic behaviour may be controlled by a connected network of 
fluid-filled cracks within fault zones. These authors established a relationship between earthquakes and increase in fluid within the rock units. [28] suggests that the large amount of water and solute load that enters the ODR yearly plays a major role in the tectonic activities of the area. A more similar example to what has been postulated by [28] regarding the ODR is one reported by scientists studying the Oklahoma earthquake, where they suggested that the injection of fluids could trigger earthquakes large enough to damage nearby structures [29].

Figure 4 shows a $b$-value of 1.2 which suggests that Botswana is a low stress area, dominated by small to moderate seismic events (Figure 5). There is a decreasing number of seismic events above the threshold magnitude $\left(M_{C}=3.8\right)$. Larger earthquakes occur less frequently i.e. ten times as many earthquakes larger than magnitude 4 occur in a particular time period than earthquakes larger than magnitude 5. Most of the seismic activity is attributable to either tectonic boundaries or sedimentary basins. A number of seismic events are also observed in the Nossop Ncojane Basin, within the Passarge Basin and at the south western edge of the Central Sub-Kalahari Basin in varying numbers and magnitudes. The boundaries of the Central Kalahari Karoo Basin have been defined as the tectonic boundaries [30]. These boundaries are the Zoetfontein Fault, Limpopo Mobile Belt, the Okavango Dyke Swarm to the North and the Kalahari Line to the west. Therefore, apart from the evidence of sedimentation noticeable moving from the Kalahari line towards the Zoetfontein Fault, seismic activities in these zones can also be thought of as due to tectonic activities along these tectonic boundaries.

The rate of seismicity between the Kunyere and Thamalakane faults and the ODR as a whole is no longer significant as compared to the years of 1966 to 1983.With strengthened monitoring systems the level of seismic activity recorded has since increased on the eastern part of the country during the period 1984-2006, and increased considerably from 2008 to 2011 (Figure 6) in the south eastern part. In this period, seismic events appear to be concentrated at the Tuli Basin, along the Zoetfontein Fault, and also denser between the Kalahari Line, Makgadikgadi Line and above the WSW end of the Zoetfontein Fault. The Zoetfontein Fault is an extension of sub-parallel post-Karoo faults such as the Melinda Fault, from South Africa into Botswana, which formed as a result of the reactivation of the east-northeast trending Palala Shear Zone [9]. Similarly, the Makgadikgadi Line has been interpreted to coincide with a NE-SW axis of enhanced seismicity which separate large domains with contrasting gravity and aeromagnetic signatures, and which have been interpreted as a tectonic front [8].

\section{Conclusion}

The main area of seismicity in Botswana was the Okavango Delta Region in Ngamiland East, in the period of 1966-1983. However, this study shows that seismicity is distributed not only on the northern part of Botswana, but also in other parts of the country such as the Southern (including Kweneng East and West), Central and Eastern Botswana. The region that seems to have the highest 
micro-seismic activity currently occurs in the south western part of the country, the Kweneng west region. However, these findings contradict those from [23], therefore, the recently expanded national network to monitor seismicity in the whole country of Botswana rather than only focusing on the ODR, will be handy in an attempt to achieve a better picture of Botswana's seismicity and probably contribute positively towards hazard mitigation.

\section{Acknowledgements}

We give special thanks to the International Seismological Centre and other contributing Organisations for the data used. We greatly appreciate valuable comments that improved this manuscript from the anonymous reviewers.

\section{Conflicts of Interest}

The authors declare no conflicts of interest regarding the publication of this paper.

\section{References}

[1] Dietvorst, E.J.L., De Vries, J.J. and Gieske, A. (1991) Coincidence of Well Fields and Tectonic Basins in the Precambrian Shield Area of Southeast Botswana. Groundwater, 29, 869-877. https://doi.org/10.1111/j.1745-6584.1991.tb00574.x

[2] Reeves, C.V. (1971) The Seismicity of Botswana. Unpublished Internal Report CVR/1/71, Department of Geological Survey, Lobatse.

[3] Hutchins, D.G., Hutton, L.G., Hutton, S.M., Jones, C.R. and Loenhert, E.P. (1976) A Summary of the Geology, Seismicity, Geomorphology and Hydrogeology of the Okavango Delta, Geological Survey, Botswana, Bulletin 7.

[4] Simon, R.E., Kwadiba, M.T.O., King, J.G. and Moidaki, M. (2012) A History of Botswana's Seismic Network, Botswana Notes and Records, 44.

[5] Modisi, M.P., Atekwana, E.A., Kampunzu, A.B. and Ngwisanyi, T.H. (2000) Rift Kinematics during the Incipient Stages of Continental Extension: Evidence from the Nascent Okavango Rift Basin, North-West Botswana. Geology, 28, 939-942. https://doi.org/10.1130/0091-7613(2000)28<939:RKDTIS>2.0.CO;2

[6] Kinabo B.D., Hogan, J.P., Atekwana, E.A., Abdelsalam, M.G. and Modisi, M.P. (2008) Fault Growth and Propagation during Incipient Continental rifting: Insights from a Combined Aeromagnetic and Shuttle Radar Topography Mission Digital Elevation Model Investigation of the Okavango Rift Zone, Northwest Botswana. Tectonics, 27, TC3013. https://doi.org/10.1029/2007TC002154

[7] McIntyre, C. (2003) Botswana: The Bradt Travel Guide. Bradt Travel Guides.

[8] Carney, J.N., Aldiss, D.T. and Lock, N.P. (1994) The Geology of Botswana. Bulletin Vol. 37. Department of Geological Survey, Lobatse, Botswana, 113 p.

[9] McCouri, S. and Vearncombe, J.R. (1987) Shear Zones Bounding the Central Zone of the Limpopo Mobile Belt, Southern Africa. Journal of Structural Geology, 9, 127-137. https://doi.org/10.1016/0191-8141(87)90021-6

[10] McCarthy, T.S. (2013) The Okavango Delta and Its Place in the Geomorphological Evolution of Southern Africa. South African Journal of Geology, 116, 1-54. https://doi.org/10.2113/gssajg.116.1.1

[11] International Seismological Centre (2012) EHB Bulletin. International Seismologi- 
cal Centre, Thatcham. http://www.isc.ac.uk

[12] Alabi, A.A., Akinyemi, O.D. and Adewale, A. (2012) Seismicity Pattern in Southern Africa from 1986 to 2009. Earth Science Research, 2, p1. https://doi.org/10.5539/esr.v2n2p1

[13] Holmstrand, P. (2010) Batchgeo. http://www.batchgeo.com

[14] Abercrombie, R.E. (1995) Earthquake Source Scaling Relationships from -1 to $5 \mathrm{ML}$ Using Seismograms Recorded at 2.5-km Depth. Journal of Geophysical Research: Solid Earth, 100, 24015-24036. https://doi.org/10.1029/95JB02397

[15] Ishimoto, M. and Iida, K. (1939) Observations of Earthquakes Registered with the Micro Seismograph Constructed Recently. Bulletin of the Earthquake Research Institute, 17, 443-478.

[16] Gutenberg, B. and Richter, C.F. (1944) Frequency of Earthquakes in California. Bulletin of the Seismological Society of America, 34, 185-188.

[17] Al-Heety, E.A. (2011) Variation of b-Value in the Earthquake Frequency-Magnitude Distribution with Depth in the Intraplate Regions.

[18] Petersen, M.D., Mueller, C.S., Moschetti, M.P., Hoover, S.M., Rubinstein, J.L., Llenos, A.L., Michael, A.J., Ellsworth, W.L., McGarr, A.F., Holland, A.A. and Anderson, J.G. (2015) Incorporating Induced Seismicity in the 2014 United States National Seismic Hazard Model: Results of the 2014 Workshop and Sensitivity Studies (No. 2015-1070) US Geological Survey. https://doi.org/10.3133/ofr20151070

[19] Wiemer, S. and Schorlemmer, D. (2007) ALM: An Asperity-Based Likelihood Model for California. Seismological Research Letters, 78, 134-140.

https://doi.org/10.1785/gssrl.78.1.134

[20] Wiemer, S. (2000) Earthquake Statistics and Earthquake Prediction Research. Institute of Geophysics, Zürich.

[21] Zuniga, R. and Wyss, M. (1995) Inadvertent Changes in Magnitude Reported in Earthquake Catalogues: Influence on b-Value.

[22] Scholz, C.H. (1975) Seismicity, Tectonics and Seismic Hazard of the Okavango Delta, Botswana. Final Report to the United Nations Development Programme on the Okavango Delta, Food and Agricultural Organization of UN, and Geological Survey and Mines Department, Botswana. UNDP/FAO BOT/71/506. Lamont-Doherty Geological Observatory of Columbia University, Palisades, New York.

[23] Reeves, C.V. (1972) Rifting in Kalahari? Nature, 237, 95-96. https://doi.org/10.1038/237095a0

[24] Unsworth, M. and Bedrosian, P.A. (2004) Electrical Resistivity Structure at the SAFOD Site from Magnetotelluric Exploration. Geophysical Research Letters, 31.

[25] Unsworth, M., Egbert, G.D. and Booker, J. (1999) High-Resolution Electromagnetic Imaging of the San Andreas Fault in Central California.

[26] Bedrosian, P.A., Unsworth, M.J., Egbert, G.D. and Thurber, C.H. (2004) Geophysical Images of the Creeping Segment of the San Andreas Fault: Implications for the Role of Crustal Fluids in the Earthquake Process. Tectonophysics, 385, 137-158. https://doi.org/10.1016/j.tecto.2004.02.010

[27] Ritter, O., Hoffmann-Rothe, A., Bedrosian, P.A., Weckmann, U. and Haak, V. (2005) Electrical Conductivity Images of Active and Fossil Fault Zones. Geological Society, London, Special Publications, 245, 165-186. https://doi.org/10.1144/GSL.SP.2005.245.01.08

[28] Shemang, E.M. and Molwalefhe, L.N. (2011) Geomorphic Landforms and Tectonism along the Eastern Margin of the Okavango Rift Zone, North Western Botswana 
as Deduced From Geophysical Data in the Area. Department of Geology, University of Botswana, Gaborone Botswana.

[29] Weingarten, M., Ge, S., Godt, J.W., Bekins, B.A. and Rubinstein, J.L. (2015) High-Rate Injection Is Associated with the Increase in US Mid-Continent Seismicity. Science, 348, 1336-1340. https://doi.org/10.1126/science.aab1345

[30] Gharbaharan, L. (2014) Regional Structure of the Central Kalahari Sub-Basin and the Geometry and Effect of the Dolerite Sills in the Area. Doctoral Dissertation, University of the Western Cape. 